\title{
PENGEMBANGAN MODUL BERBASIS BOUNDED INQUIRY LAB UNTUK MENINGKATKAN LITERASI SAINS DIMENSI KONTEN PADA MATERI SISTEM PENCERNAAN KELAS XI
}

\author{
Renny Widya Kusuma Sanjaya ${ }^{1}$, Maridi $^{2}$, Suciati $^{3}$ \\ ${ }^{1}$ Program Studi Magister Pendidikan Sains FKIP Universitas Sebelas Maret \\ Surakarta, 57126, Indonesia \\ rain.nie91@gmail.com \\ ${ }^{2}$ Program Studi Magister Pendidikan Sains FKIP Universitas Sebelas Maret \\ Surakarta, 57126, Indonesia \\ maridi_uns@yahoo.co.id \\ ${ }^{3}$ Program Studi Magister Pendidikan Sains FKIP Universitas Sebelas Maret \\ Surakarta, 57126, Indonesia \\ suciati.sudarisman@yahoo.com
}

\begin{abstract}
Abstrak
Penelitian bertujuan untuk: 1) Mengetahui karakteristik modul berbasis bounded inquiry lab untuk meningkatkan literasi sains dimensi konten pada materi Sistem Pencernaan kelas XI; 2) Menguji kelayakan modul biologi berbasis bounded inquiry lab untuk meningkatkan literasi sains dimensi konten pada materi Sistem Pencernaan kelas XI dan; 3) Menguji keefektivan penggunaan modul berbasis bounded inquiry lab untuk meningkatkan literasi sains dimensi konten pada materi Sistem Pencernaan kelas XI. Penelitian dan pengembangan modul menggunakan prosedur Borg \& Gall (1983) yang telah dimodifikasi yang meliputi 10 tahap: 1) tahap penelitian dan pengumpulan informasi; 2) tahap perencanaan; 3) tahap pengembangan desain; 4) tahap uji coba lapangan awal; 5) tahap revisi produk pertama; 6) tahap uji coba lapangan utama; 7) tahap revisi produk kedua; 8) tahap uji lapangan operasional; 9) tahap revisi produk akhir dan; 10) Diseminasi dan implementasi modul. Subjek pengembangan meliputi responden uji coba lapangan awal berjumlah 4 validator ahli dan 2 praktisi, respon uji skala kecil berjumlah 10 peserta didik. Responden uji coba lapangan utama/keefektivan berjumlah 65 peserta didik yang terdiri atas 2 kelas menggunakan modul yaitu 32 peserta didik kelas XI MIA 1 dan 33 peserta didik kelas XI MIA 4. Data kemampuan literasi sains dimensi konten dianalisis dengan $N$-Gain ternormalisasi untuk mengetahui keefektivan modul berbasis bounded inquiry lab. Hasil penelitian dan pengembangan menunjukkan: 1) Modul berbasis bounded inquiry lab untuk meningkatkan literasi sains dimensi konten pada materi Sistem Pencernaan dikembangkan sesuai dengan tahapan bounded inquiry lab (observasi, manipulasi, generalisasi, verifikasi, aplikasi) dan pendekatan saintifik; 2) Kelayakan modul berbasis bounded inquiry lab dikategorikan sangat baik; 3) Keefektivan modul yang dikembangkan berbasis bounded inquiry lab dibuktikan dengan uji Wilcoxon yang menunjukkan ada perbedaan dalam literasi sains dimensi konten sebelum dan sesudah menggunakan modul berbasis bounded inquiry lab memiliki probabilitas (p) sebesar 0,000 ( $<<0,05), \mathrm{H}_{\mathrm{o}}$ ditolak. Berdasarkan hasil penelitian dapat disimpulkan bahwa modul berbasis bounded inquiry lab layak dan efektif meningkatkan literasi sains dimensi konten pada materi Sistem Pencernaan kelas XI.
\end{abstract}

Kata kunci: modul, bounded inquiry lab, literasi sains dimensi konten, sistem pencernaan

\section{Pendahuluan}

Abad ke-21 merupakan era globalisasi yang penuh tantangan. Perkembangan sains dan teknologi di segala bidang sangat pesat, salah satunya adalah bidang pendidikan. Pendidikan Indonesia diharapkan dapat menghadapi sejumlah tantangan. Menurut
National Science Teachers Association (2006) tantangan abad 21 meliputi, kemampuan berpikir kreatif, inovatif, berpikir kritis, kemampuan memecahan masalah, komunikasi, kolaborasi, melek teknologi (ICT Literacy) dan kepemimpinan, sehingga dibutuhkan sumber daya manusia (SDM) yang berkualitas serta 
mampu berkompetisi. SDM yang berkualitas, yang dihasilkan oleh pendidikan yang berkualitas dapat menjadi kekuatan utama dalam menghadapi masalah-masalah bidang pendidikan.

Pendidikan diharapkan dapat menjadi jembatan yang menghubungkan individu dengan lingkungannya di era globalisasi yang semakin berkembang pesat, sehingga individu mampu berperan sebagai SDM yang berkualitas. Menurut Sumartati (2009) menyatakan bahwa proses pendidikan diharapkan mampu membentuk manusia yang melek sains dan teknologi.

Sains sangat penting perannya dalam mendorong kemajuan Ilmu Pengetahuan dan Teknologi (IPTEK) (Suciati, 2011). Sains berperan meningkatkan nilai, sikap, dan kemampuan berpikir untuk menghasilkan peserta didik yang berkualitas mampu menghadapi masalah. Pendidikan sains memiliki potensi besar menyiapkan sumber daya manusia yang berkualitas dalam menghadapi era globalisasi.

Pendidikan sains memiliki peran yang penting dalam menyiapkan peserta didik memasuki dunia nyata. Sains yang sarat akan kegiatan berpikir dapat menjadi wahana untuk meningkatkan kualitas SDM Indonesia, terutama dalam membangun keterampilan berpikirnya. Pembentukan keterampilan ini sangat menentukan dalam membangun kepribadian dan pola tindakan dalam kehidupan setiap insan Indonesia, karena itu pembelajaran sains perlu diberdayakan untuk mencapai maksud tersebut. pembelajaran sains bertanggung jawab atas literasi sains peserta didik, kualitas sains perlu ditingkatkan agar dapat mencapai taraf pengembangan yang berkelanjutan (Liliasari, 2012).

Pembelajaran sains sebagai salah satu pendorong kemajuan teknologi informasi dan komunikasi pada era globalisasi harus diajarkan sesuai dengan hakikat pembelajaran sains yang mencakup sikap, proses dan produk (Toharudin, 2011). Sikap dalam proses pembelajaran sains lebih menekan kepada pembentukan sikap ilmiah berupa karakter dan ketrampilan sosial meliputi rasa ingin tahu, jujur, toleran, terbuka, tekun, berani bekerjasama, optimis, skeptis dan bekerjasama. Produk dalam pembelajaran sains lebih menekankan pada penerapan metode ilmiah atau aplikasinya dalam kehidupan sehari-hari. Proses dalam pembelajaran sains lebih menekankan penggunaan prosedur pemecahan masalah melalui metode ilmiah. Proses sains akan memungkinkan seseorang untuk membuat suatu keputusan dengan pengetahuan yang dimilikinya.

Tujuan pendidikan sains khususnya biologi SMA sesuai Permendiknas No. 69 Tahun 2013 adalah mempersiapkan manusia Indonesia memiliki kemampuan hidup pribadi dan warga negara yang beriman, produktif, kreatif, inovatif, dan afektif serta mampu mengaplikasikan dan berkontribusi pada kehidupan masyarakat, bangsa, negara, dan peradaban dunia. Hal tersebut relevan dengan Kurikulum 2013 yang menekankan pada dimensi pedagogik modern dalam pembelajaran yaitu menggunakan pendekatan ilmiah. Pendekatan ilmiah merupakan pembelajaran yang mengadopsi langkahlangkah sainstis dalam membangun pengetahuan melalui metode ilmiah. Pendekatan ilmiah (scientific approach) dalam pembelajaran meliputi: mengamati, menanya, menalar, mencoba, membentuk jejaring untuk semua mata pelajaran. Penguatan pendekatan ilmiah dalam pembelajaran perlu diterapkan model pembelajaran berbasis penelitian dan pemecahan masalah seperti discovery, inquiry, project based learning dan problem based learning (Kemendikbud, 2013).

Menurut Liliasari (2011) Pembelajaran sains ditujukan untuk melatih peserta didik menguasai pengetahuan dan pemahaman konsep-konsep serta proses sains yang diperlukan untuk pengambilan keputusan pribadi dengan cara berpartisipasi dalam kegiatan masyarakat dan budaya, serta produktivitas ekonomi, sehingga peserta didik mampu menghadapi tantangan abad 21. Dalam hal ini tersirat peranan serta kewajiban pendidikan sains dalam membentuk warga negara yang melek sains.

Literasi sains penting untuk dikuasai oleh peserta didik dalam kaitannya dengan bagaimana peserta didik dapat memahami 
lingkungan hidup, kesehatan, ekonomi dan masalah-masalah lain yang dihadapi oleh masyarakat modern yang sangat bergantung pada teknologi dan kemajuan serta perkembangan ilmu pengetahuan (Yusuf, 2003). Menurut National Research Council (Susanti, 2012) menyatakan pentingnya literasi sains dikembangkan karena: 1) pemahaman terhadap sains menawarkan kepuasan dan kesenangan pribadi yang muncul setelah memahami dan mempelajari alam; 2) kehidupan sehari-hari, setiap orang memerlukan informasi dan berpikir ilmiah dalam mengambil keputusan; 3) setiap orang perlu melibatkan kemampuan mereka dalam wacana publik dan debat mengenai isu penting yang melibatkan sains dan teknologi; 4) literasi sains penting dalam dunia kerja, sehingga perlu adanya pengorganisasian didalam mengembangkan literasi sains peserta didik.

Literasi sains ini bersifat
multidimensional dalam aspek pengukurannya yaitu dalam konten sains, proses sains, dan konteks aplikasi (PISA, 2006). Konten sains yaitu merujuk kepada konsep-konsep kunci dari sains yang diperlukan untuk memahami fenomena alam dan perubahan yang terjadi akibat kegiatan manusia, namun tidak secara khusus membatasi cakupan konten sains hanya pada pengetahuan yang menjadi materi kurikulum sains di sekolah, tetapi termasuk pula pengetahuan yang dapat diperoleh melalui sumber-sumber informasi lain yang tersedia. Proses sains mengkaji kemampuan peserta didik untuk menggunakan pengetahuan dan pemahaman ilmiah, seperti kemampuan peserta didik untuk mencari, menafsirkan dan memperlakukan bukti-bukti. Ada tiga aspek dari proses sains berikut dalam penilaian literasi sains, yakni mengidentifikasi pertanyaan ilmiah, menjelaskan fenomena secara ilmiah, dan menggunakan bukti ilmiah. Konteks sains lebih melibatkan isu-isu yang sangat penting dalam kehidupan sehari- hari (Toharudin, 2011).

Pengembangan literasi sains lebih efektif melalui pembelajaran yang mandiri. Pembelajaran biologi perlu didukung dengan bahan ajar yang mendorong peserta didik mandiri, sehingga menuntun peserta didik menemukan konsep melalui kegiatan penemuan sebagaimana disarankan dalam pembelajaran kurikulum 2013. Bahan ajar merupakan sarana pembelajaran dalam bentuk cetak disusun secara sistematis, terdapat materi pembelajaran, metode pembelajaran, tujuan pembelajaran, berdasarkan kompetensi atau indikator pencapaian kompetensi, petunjuk kegiatan belajar mandiri, dan memberikan kesempatan kepada peserta didik untuk menguji diri sendiri melalui latihan (Prastowo, 2012). Bahan ajar mandiri seharusnya terdapat kegiatan merancang suatu percobaan, ada kegiatan percobaan, yang mana kegiatan tersebut mampu menjadikan pembelajaran lebih bermakna dan tidak hanya menghafal materi namun mampu memahami dan mengaitkan materi dengan lingkungan sekitarnya sehingga mampu meningkatkan kualitas peserta didik.

Namun fakta di lapangan menunjukkan bahwa kemampuan literasi sains peserta didik di Indonesia masih rendah. Studi PISA oleh OECD (Organization for Economic Cooperation and Development) dilakukan setiap 3 tahun sekali agar dapat memperoleh informasi yang berkesinambungan mengenai prestasi belajar peserta didik untuk mengetahui tingkat kualitas pendidikan Indonesia di dalam lingkup Internasional. PISA menunjukkan bahwa rata-rata kemampuan literasi sains peserta didik peserta didik Indonesia pada tahun 2000 berada pada peringkat 38 dari 41 negara peserta, pada tahun 2003 Indonesia tetap berada pada peringkat 38 dari 40 negara peserta, pada tahun 2006 peringkat 50 dari 57 negara peserta, dan tahun 2009 peringkat 60 dari 65 negara. Hasil PISA 2012 peringkat literasi sains Indonesia turun pada posisi 64 dari 65 negara dengan skor 382 (OECD, 2012). Berdasarkan hasil studi PISA tersebut membuktikan bahwa rata-rata peserta didik Indonesia memiliki kemampuan literasi sains yang rendah dibandingkan dengan rata-rata Internasional yang mencapai skor 500 (Toharudin, 2011). Rata-rata kemampuan sains peserta didik Indonesia menurut capaian tersebut, baru sampai pada kemampuan mengenali sejumlah fakta dasar, tetapi mereka belum mampu untuk mengkomunikasikan dan 
mengaitkan kemampuan itu dengan berbagai topik sains, apalagi menerapkan konsepkonsep yang kompleks dan abstrak.

Rendahnya literasi sains juga terjadi di SMA Negeri 5 Surakarta. Hasil pra-riset berupa pemberian soal terjemahan literasi sains dari PISA (2006) didapatkan bahwa capaian hasil konteks sains sebesar 15,56 \%, proses sains sebesar 17,11\% dan konten sains sebesar 13,22\% (Sanjaya, 2014). Hal ini menunjukkan bahwa literasi sains peserta didik SMA Negeri 5 masih rendah, terutama dari aspek konten sains. Rendahnya diprediksi karena peserta didik cenderung hanya menitikberatkan pada aspek hafalan, sehingga peserta didik tidak memahami apa yang telah dipelajari tetapi hanya sebatas mengingat yang sewaktu-waktu dapat dengan mudah terlupakan. Hal ini diperkuat dari hasil wawancara dengan guru bahwa peserta didik kurang dapat menganalisis soal yang berbentuk perubahan fenomena yang berkaitan dengan materi, karena cenderung menghafal materi yang terdapat di buku dan yang dijelaskan oleh guru.

Merujuk pada rendahnya literasi sains dimensi konten peserta didik tersebut, selanjutnya dilakukan penelusuran melalui angket. Hasil analisis angket tentang pemberdayaan kemampuan literasi sains menunjukkan bahwa peserta didik merasa kesulitan memahami konsep-konsep biologi yang melibatkan kemampuan memecahkan masalah. Guru kurang melatihkan peserta didik untuk menyelesaikan masalah dengan menggunakan konsep sains sehingga peserta didik kesulitan dalam memahami konsep yang abstrak.

Berdasarkan hasil observasi di SMA Negeri 5 Surakarta melalui analisis 8 Standar Nasional Penilaian (SNP) Tahun 2014 yang menunjukkan bahwa terdapat gap pada standar nomor 2 yaitu standar proses sebesar 2,84\% (Sanjaya, 2013). Rendahnya standar proses menunjukkan bahwa guru mengedepankan aspek produk dibandingkan proses. Kondisi umum yang ditemukan di kelas meliputi fungsi guru dominan dan peserta didik kurang aktif dalam kegiatan pembelajaran.

Ditinjau dari pemetaan materi biologi khususnya materi tentang sistem pencernaan masih rendah. Hasil analisis UN menurut BSNP tahun 2012/2013 menunjukkan persentase penguasaan materi sistem organ paling rendah di SMA Negeri 5 Surakarta; pada tingkat sekolah mencapai 61,71 , pada tingkat Kota/Kabupaten 58,98, pada tingkat provinsi 61,04, dan pada tingkat nasional 60,70 , sedangkan persentase daya serap pada materi sistem pencernaan di SMA $\mathrm{N} 5$ Surakarta; pada tingkat sekolah mencapai 65,08 , pada tingkat kota/kabupaten 60,44 , pada tingkat provinsi 57,43 , dan pada tingkat nasional 60,56. Berdasarkan data tersebut penguasaan pada materi sistem pencernaan masih dibawah rata-rata. Karakteristik dari materi sistem pencernaan cenderung pada pemahaman dan pengaitan materi dengan kehidupan sehari-hari yang belum begitu dipahami oleh peserta didik sehingga nilai belum mencapai ketuntasan dan belum sesuai dengan karakteristik materi. Peserta didik kurang terbiasa melakukan kegiatan merancang percobaan dan melakukan penyelidikan untuk menemukan konsep sendiri guna meningkatkan literasi sains dimensi konten sehingga pembelajaran biologi hanya cenderung mempelajarinya sebagai produk, konsep, dan teori. Hal ini mengakibatkan peserta didik mengalami kesulitan dalam menghubungkan antara perubahan fenomena dengan kehidupan sehari-hari dalam menggunakan informasi sains yang ada untuk memecahkan masalah yang terjadi.

Berdasarkan analisis proses belajar mengajar (PBM) di kelas menunjukkan bahwa metode pembelajaran yang digunakan guru bersifat konvensional, cara penyampaian materi yang digunakan bersifat teacher center learning, dalam kegiatan pembelajaran sering menggunakan media, guru hanya melakukan pengukuran pada aspek pengetahuan dan keterampilan, dan guru mengajar sesuai dengan alokasi pada silabus, kalender akademik, dan RPP (Sanjaya, 2014). Hasil analisis observasi menunjukkan bahwa pembelajaran di kelas berpusat pada guru sebagai sumber informasi, pemberi konsep, kurang melatihkan peserta didik dalam menerapkan konsep fenomena dalam kehidupan sehari-hari. 
Kegiatan peserta didik di kelas ketika PBM menunjukkan bahwa peserta didik masih mengalami kesulitan dalam belajar biologi. Hal ini dapat terlihat ketika keaktifan peserta didik dalam kegiatan belajar mengajar di kelas cukup aktif diperoleh persentase sebesar 62,07 $\%$, kemampuan bekerjasama peserta didik dalam kegiatan diskusi masih rendah, kemampuan memecahkan masalah masih rendah (Sanjaya, 2014). Hasil analisis observasi menunjukkan bahwa peserta didik kurang terlatihkan kemampuan menemukan solusi. Peserta didik dalam pembelajaran kurang berkembang menemukan solusi melalui proses penyelidikan, sehingga kemampuan literasi sains peserta didik masih rendah. Rendahnya literasi sains terlihat ketika peserta didik belum mampu mengaitkan pengetahuan yang didapat melalui pembelajaran dengan kehidupan sehari-hari.

Pembelajaran tidak lepas dari perangkat pembelajaran, salah satunya bahan ajar. Selanjutnya dilakukan analisis bahan ajar yang digunakan di sekolah. Berdasarkan hasil analisis dan wawancara dengan guru biologi ternyata materi bahan ajar bahan ajar tidak dilengkapi dengan kegiatan merancang, materi sangat lengkap, materi bersifat textual, soal hanya berupa kemampuan mengingat dan pemahaman, bahasa tidak komunikatif, tampilan gambar tidak berwarna, daftar istilah, namun ada beberapa kata sulit yang tidak terdapat di glosarium (Sanjaya, 2014). Bahan ajar di SMA Negeri 5 Surakarta ternyata juga masih belum memaksimalkan literasi sains. Berdasarkan analisis bahan ajar di SMA Negeri 5 Surakarta untuk literasi sains pada materi sistem pencernaan hanya diperoleh $3,63 \%$ untuk tujuan pembelajaran dan materi pembelajaran, $0 \%$ untuk aktivitas, serta $5,45 \%$ untuk soal evaluasi (Sanjaya, 2014). Analisis bahan ajar ini menggunakan indikator literasi sains dimensi konten menurut PISA (2012). Bahan ajar lebih menekankan pada produk hasil daripada proses, belum mengarahkan peserta didik belajar mandiri dalam menemukan konsep. Hal tersebut menyebabkan peserta didik kurang terlatihkan berpikir tingkat tinggi dan keterampilan proses melalui kegiatan penyelidikan sehingga kegiatan belajar kurang bermakna.

Berdasarkan penjelasan terdapat kesenjangan antara kondisi ideal dan fakta, maka diperlukan pegembangan bahan ajar yang bersifat mandiri dalam kegiatan mengajar. Pembelajaran biologi perlu didukung dengan bahan ajar mandiri yang mendorong peserta didik menemukan konsepkonsep materi melalui penyelidikan.

Model inquiry bertujuan untuk mendorong peserta didik agar dapat mengembangkan disiplin intelektual dan keterampilan berpikir dengan memberikan pertanyaan-pertanyaan (Suyanti, 2010). Model inquiry dapat membantu guru mengaitkan antara materi yang diajarkan dengan kondisi dunia nyata dan memotivasi peserta didik menghubungkan antara pengetahuan yang dimilikinya dan penerapannya dalam kehidupan sehari-hari. Model inquiry ini menjadikan pembelajaran lebih bermakna, sehingga peserta didik tidak hanya menghafal materi pembelajaran namun membantu peserta didik memahami materi dan mampu mengaitkan dengan kehidupan sehari-hari. Hal ini diharapkan dapat meningkatkan literasi sains peserta didik.

Wenning (2011) mengklasifikasikan inquiry menjadi 8 level. Penetapan level tersebut berdasarkan pada sejauh mana fokus kontrol antara peserta didik dan kompleksitas pengalaman intelektual yang diperolehnya selama proses pembelajaran. Level inquiry ini terdiri dari discovery learning, interactive demonstration, inquiry lesson, guided inquiry lab, bounded inquiry lab, free inquiry lab, pure hypothetical inquiry dan yang paling tinggi tingkatnya applied hypothetical inquiry. Masing-masing level inquiry memiliki karakteristik sendiri.

Hasil analisis tes penguasaan indikator inquiry peserta didik SMA Negeri 5 Surakarta menunjukkan bahwa peserta didik menguasai pada indikator inquiry yang merupakan bagian dari guided inquiry laboratory lab, sehingga perlu ditingkatkan dan harus siap untuk melaksanakan ke indikator inquiry satu tahap yang lebih tinggi yaitu indikator inquiry yang merupakan bagian dari bounded inquiry lab 
(Sanjaya, 2014). Karakteristik dari bounded inquiry lab yaitu terdapat peningkatan pada kemampuan dan kemandirian peserta didik untuk merancang dan mengadakan eksperimen tanpa banyaknya panduan dari guru serta adanya pre-lab yang jelas. Kegiatan pre-lab yang berfokus pada non-eksperimen seperti aspek keselamatan kerja laboratorium serta penggunaan perlindungan peralatan laboratorium. Adapun sintaks bounded inquiry lab adalah observasi (mengidentifikasi masalah dan merancang percobaan), manipulasi (melakukan percobaan), generalisasi (mengolah data), verifikasi (mengkomunikasikan data) dan aplikasi, melalui sintaks ini peserta didik tidak hanya menghafal materi namun menemukan konsep melalui penyelidikan sendiri sehingga literasi sains dapat ditingkatkan. Kelebihan bounded inquiry lab adalah mampu melatih kemandirian peserta didik namun tetap memperhatikan keselamatan kerja dan penggunaan perlindungan peralatan laboratorium melalui kegiatan pre-lab, sehingga pembelajaran akan lebih bermakna dan mampu meningkatkan pemahaman peserta didik (Wenning 2011).

Penggunaan bounded inquiry lab relevan dengan karakteristik peserta didik di SMA Negeri 5 Surakarta. Berdasarkan wawancara dengan guru menunjukkan bahwa praktikum yang dilakukan dengan bimbingan dari guru, kegiatan keselamatan kurang diperhatikan hanya menuntut peserta didik untuk menggunakan jas laboratorium, dan belum ada prosedur cara penggunaan alat dan bahan laboratorium yang tepat serta tidak adanya asisten laboratorium yang bertugas mengawasi berlangsungnya praktikum. Sesuai dengan penilitian dari Johnson (2006) yang menyatakan bahwa kekurangan SDM untuk mengawasi sejumlah besar peserta didik yang melakukan kegiatan praktikum di laboratorium, akibatnya Johnson mengadospsi model yang dinamai penyelidikan terbatas alias bounded inquiry lab. Hasil wawancara dengan peserta didik menunjukkan bahwa tidak ada kegiatan pre-lab tentang keselamatan kerja di laboratorium dan penggunaan alat dan bahan laboratorium yang aman, sehingga peserta didik tidak berhati-hati dalam melakukan praktikum. Berdasarkan observasi data buku inventaris laboratorium terdapat beberapa peserta didik yang memecahkan peralatan laboratorium terutama alat yang terbuat dari kaca. Pengunaan model bounded inquiry lab mampu mengatasi permasalahan tersebut, dengan adanya prosedur keselamatan kerja dan penggunaan alat dan bahan laboratorium yang aman, sehingga peserta didik lebih berhati-hati di laboratorium. Hal ini relevan dengan Permendiknas No 64 Tahun 2013 tentang Standar Isi Pendidikan Dasar dan Menengah pada kompetensi kelas X-XI IPA khususnya biologi bahwa menerapkan proses kerja ilmiah dan keselamatan kerja di laboratorium biologi perlu dalam pengamatan dan percobaan untuk memahami permasalahan biologi pada berbagai objek dan bioproses, serta mengaitkan biologi dengan lingkungan teknologi, dan masyarakat di abad XXI.

Modul berbasis bounded inquiry lab merupakan modul yang membimbing peserta didik untuk mandiri merancang dan melakukan eksperimen sendiri dengan sedikit panduan dari guru dan adanya kegiatan pre-lab. Level ini guru hanya sedikit memberikan pertanyaan panduan pada peserta didik, peserta didik diminta untuk mengidentifikasi masalah, memformulasikan suatu eksperimen dari masalah, merumuskan masalah, membuat hipotesis, merancang eksperimen, peserta didik diminta untuk melakukan eksperimen sendiri, menarik kesimpulan dari eksperimen dan mengaplikasikan hasil eksperimen dengan kehidupan sehari-hari. Modul berbasis bounded inquiry lab merupakan modul yang sesuai untuk meningkatkan literasi sains dimensi konten, karena memuat serangkaian kegiatan sistematika sehingga peserta didik terlatihkan pembelajaran yang bermakna dan tidak terpaku pada hafalan semata.

Modul berbasis bounded inquiry lab yang khusus dikembangkan pada materi Sistem Pencernaan diharapkan mampu membantu peserta didik untuk belajar secara mandiri dalam menemukan konsep dan mempelajari serta memahami konten materi dengan mendalam karena dikembangkan melalui proses penyelidikan, sehingga mampu 
meningkatkan literasi sains dimensi konten, dan mengubah pandangan peserta didik mengenai pembelajaran dari hafalan menjadi pemahaman. Peserta didik dilatih menemukan konsep sendiri melalui proses penyelidikan agar peserta didik memahami materi yang sedang di pelajari sehingga tidak hanya hafalan sesaat. Pemahaman peserta didik terlatihkan melalui kegiatan mengidentifikasi masalah, merumuskan masalah, merancang percobaan, melakukan percobaan, menyimpulkan hasil percobaan, dan mengaplikasikan hasil percobaan dalam kehidupan sehari-hari. Kegiatan pembelajaran dari sintaks ini mampu meningkatkan aspek konten sains.

Berdasarkan latar belakang di atas, serta dalam rangka meningkatkan kemampuan literasi sains dimensi konten maka perlu dilakukan penelitian dan pengembangan modul dengan judul pengembangan modul berbasis bounded inquiry lab untuk meningkatkan literasi sains dimensi konten pada materi Sistem Pencernaan Kelas XI.

\section{Metode Penelitian}

Penelitian ini merupakan penelitian dan pengembangan (Research \& Development) modifikasi model Borg and Gall (1983) pada tahap kesepuluh dengan prosedur pengembangan meliputi: 1) Pengumpulan data berupa analisis kebutuhan; 2) Perencanaan; 3) Pengembangan produk permulaan (draft awal), 4) Uji coba lapangan awal, 5) Revisi produk I, 6) Uji coba lapangan utama, 7) Revisi produk I, 8) Uji lapangan operasional, 9) Revisi produk III, 10) Diseminasi dan implementasi.

Subjek uji coba terdiri atas 3 kelompok meliputi uji coba lapangan awal yaitu 4 validator ahli, 2 validator praktisi implementasi SMA, dan 10 pengguna modul SMA Negeri 7 Surakarta. Subjek uji coba lapangan utama terdiri atas 2 kelas yaitu 32 peserta didik kelas XI MIA 1 dan 33 peserta didik kelas XI MIA 4 SMA Negeri 5 Surakarta. Subjek uji lapangan operasional yaitu 28 peserta didik kelas XI MIA 1 SMA Negeri 7 Surakarta dan 25 peserta didik kelas XI MIA 3 SMA Negeri 8 Surakarta.
Data analisis kebutuhan diperoleh dari mengkaji Kurikulum 2013, analisis hasil UN, analisis RPP guru, analisis pemenuhan 8 SNP, observasi dan wawancara terhadap kegiatan pembelajaran, wawancara terhadap bahan ajar, analisis bahan ajar, angket bahan ajar, analisis literasi sains pada bahan ajar, dan tes penguasaan indikator inquiry.

Data hasil kelayakan modul berupa data kuantitatif dan kualitatif berdasarkan hasil validasi dari ahli, praktisi implementasi, dan pengguna modul melalui angket kelayakan modul serta kuisioner tanggapan peserta didik terhadap modul. Data analisis deskriptif kualitatif digunakan untuk analisis data validasi dari ahli, praktisi implementasi, dan pengguna modul yang berupa saran dan masukan. Analisis deskriptif kuantitatif digunakan untuk analisis data yang berbentuk persentase. Teknik ini digunakan untuk mengetahui persentase dalam menyajikan data frekuensi atas tanggapan subjek uji coba terhadap modul pengembangan berbasis bounded inquiry lab.

Data hasil literasi sains dimensi konten dihitung dengan menggunakan uji non parametrik yaitu uji Wilcoxon dengan menggunakan bantuan SPSS 18. Uji tersebut digunakan untuk mengetahui ada atau tidaknya perbedaan hasil literasi sains dimensi konten sebelum dan sesudah menggunakan modul berbasis bounded inquiry lab. Kriteria pengambilan keputusan uji adalah apabila nilai signifikansi lebih kecil dari 0,05 maka $\mathrm{H}_{0}$ ditolak, sehingga terdapat perbedaan hasil literasi sains dimensi konten sebelum dan sesudah menggunakan modul berbasis bounded inquiry lab.

\section{Hasil Penelitian dan Pembahasan}

\section{Deskripsi Data}

1. Tahap Pengumpulan Data

Berdasarkan hasil analisis kebutuhan ditemukan permasalahan yaitu penggunaan bahan ajar kurang optimal. Ditinjau dari masalah yang ditemukan diketahui terdapat kesenjangan antara kondisi fakta dan ideal dari penggunaan bahan ajar, untuk mengatasi permasalahan di atas ditemukan solusi yaitu 
perlunya pengembangan modul yang mampu memfasilitasi aktivitas pengalaman langsung untuk menemukan konsep melalui kegiatan penyelidikan, sehingga mendorong literasi sains peserta didik.

\section{Tahap Uji Coba Lapangan Awal}

Uji coba lapangan awal merupakan tahap untuk proses validasi penelitian pengembangan meliputi 4 validator ahli, 2 validator praktisi implementasi biologi SMA, dan uji coba skala kecil dengan 10 pengguna modul SMA Negeri 7 Surakarta. Validasi terdiri atas ahli materi, ahli bahasa, ahli penyajian modul, dan ahli perangkat pembelajaran. Hasil uji coba lapangan awal disajikan pada Gambar 1.

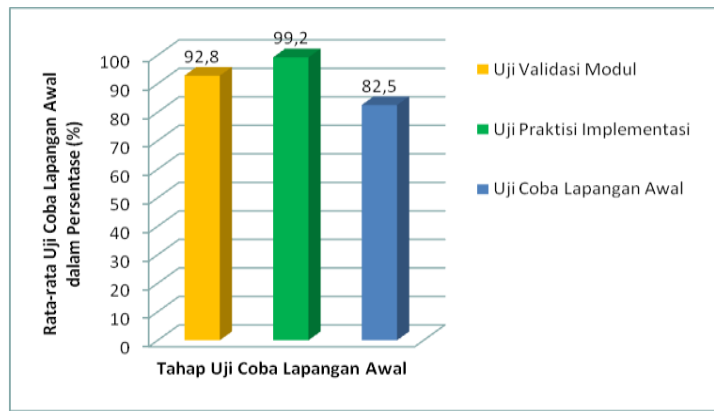

Gambar 1. Histogram Hasil Persentase Rata-rata Uji Coba Lapangan Awal

Berdasarkan data pada Gambar 1 menunjukkan bahwa hasil validasi dari validator ahli dan praktisi implementasi biologi SMA termasuk kategori "sangat baik", dan hasil tanggapan 10 pengguna modul melalui angket termasuk kategori "baik".

3. Uji Coba Lapangan Utama/Keefektivan

a. Hasil Literasi Sains Dimensi Konten

Hasil literasi sains dimensi konten diperoleh berdasarkan nilai pretest dan posttest literasi sains dimensi konten dari 32 peserta didik kelas XI MIA 1 dan 33 peserta didik kelas XI MIA 4.

1) Hasil Literasi Sains Dimensi Konten Kelas XI MIA 1.

Hasil literasi sains dimensi konten kelas XI MIA 1 disajikan pada Gambar 2.

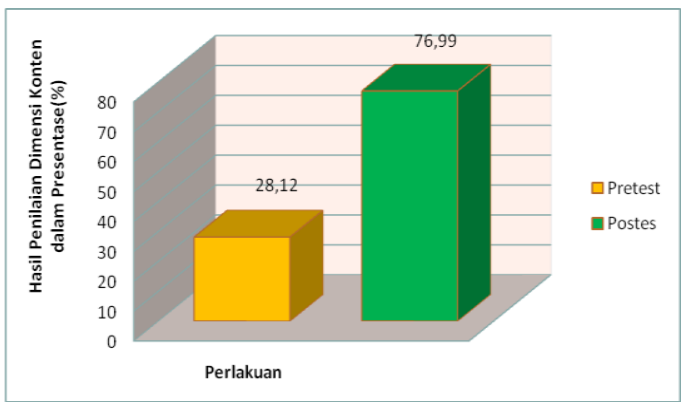

Gambar 2. Histogram Hasil Literasi Sains Dimensi Konten Kelas XI MIA 1

Selanjutnya, dilakukan uji prasyarat untuk nilai pretest dan posttest literasi sains dimensi konten kelas XI MIA 1. Hasil uji prasyarat literasi sains dimensi konten kelas XI MIA 1 disajikan pada Tabel 1.

Tabel 1. Hasil Uji Prasyarat Literasi Sains Dimensi Konten Kelas XI MIA 1

\begin{tabular}{llll}
\hline Uji & Hasil & Keputusan & Kesimpulan \\
\hline $\begin{array}{l}\text { Normalit } \\
\text { as }\end{array}$ & $\begin{array}{l}\text { Sig pretest }= \\
0.001\end{array}$ & $\mathrm{H}_{0}$ ditolak & $\begin{array}{l}\text { Data tidak } \\
\text { normal }\end{array}$ \\
& $\begin{array}{l}\text { Sig posttest } \\
=0.001\end{array}$ & $\mathrm{H}_{0}$ ditolak & $\begin{array}{l}\text { Data tidak } \\
\text { normal }\end{array}$ \\
$\begin{array}{l}\text { Homoge } \\
\text { nitas }\end{array}$ & Sig $=0.323$ & $\begin{array}{l}\mathrm{H}_{0} \\
\text { diterima }\end{array}$ & $\begin{array}{l}\text { Data } \\
\text { homogen }\end{array}$ \\
\hline
\end{tabular}

Berdasarkan data pada Tabel 1 diketahui bahwa uji prasyarat untuk nilai pretest dan posttest literasi sains dimensi konten menunjukkan bahwa nilai pretest dan data posttest terdistribusi tidak normal namun homogen.

Berdasarkan data hasil uji prasyarat, maka uji lanjut menggunakan uji non parametrik yaitu uji Wilcoxon untuk mengetahui ada tidaknya perbedaan penggunaan modul pembelajaran berbasis bounded inquiry lab. Hasil analisis dengan uji Wilcoxon kelas XI MIA 1 disajikan pada Tabel 2.

Tabel 2. Hasil Analisis Uji Wilcoxon Kelas

\begin{tabular}{llll}
\multicolumn{3}{c}{ XI MIA 1 } & \\
\hline Uji & Hasil & Keputusan & Kesimpulan \\
\hline Lanjut & $\mathrm{T}_{\text {hitung }}=-$ & $\mathrm{H}_{0}$ ditolak & Hasil tidak \\
& 5.019 & & sama \\
& $\mathrm{p}=0.000$ & & (ada beda) \\
\hline
\end{tabular}

Berdasarkan data hasil yang diperoleh pada kelas XI MIA 1 dapat disimpulkan bahwa nilai literasi sains dimensi konten peserta didik mengalami peningkatan setelah diberikan 
pembelajaran menggunakan modul berbasis bounded inquiry lab.

2) Hasil Literasi Sains Dimensi Konten Kelas XI MIA 4.

Hasil literasi sains dimensi konten kelas XI MIA 4 disajikan pada Gambar 3.

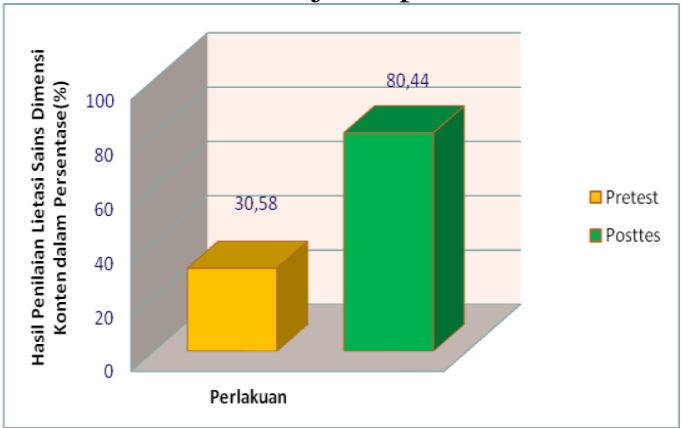

Gambar 3. Histogram Hasil Literasi Sains Dimensi Konten Kelas XI MIA 4

Selanjutnya, dilakukan uji prasyarat untuk nilai pretest dan posttest literasi sains dimensi konten kelas XI MIA 4. Hasil uji prasyarat literasi sains dimensi konten kelas XI MIA 4 disajikan pada Tabel 3.

Tabel 3. Hasil Uji Prasyarat Literasi Sains Dimensi

\begin{tabular}{llll}
\multicolumn{3}{c}{ Konten Kelas XI MIA 4 } & \\
\hline Uji & Hasil & $\begin{array}{l}\text { Keputus } \\
\text { an }\end{array}$ & Kesimpulan \\
\hline Normalitas & Sig pretest & $\begin{array}{l}\mathrm{H}_{0} \\
\text { diterima }\end{array}$ & Data normal \\
& $\begin{array}{l}\text { Sig posttest } \\
\text { Sid }\end{array}$ & $\begin{array}{l}\mathrm{H}_{0} \\
\text { ditolak }\end{array}$ & $\begin{array}{l}\text { Data tidak } \\
\text { normal }\end{array}$ \\
& $=0.002$ & Data tidak \\
Homogenit & Sig $=0.042$ & $\begin{array}{l}\mathrm{H}_{0} \\
\text { ditolak }\end{array}$ & homogen \\
\hline
\end{tabular}

Berdasarkan data pada Tabel 3 diketahui bahwa uji prasyarat untuk nilai pretest dan posttest literasi sains dimensi konten menunjukkan bahwa nilai pretest terdistribusi normal namun data posttest tidak terdistribusi normal dan tidak homogen.

Berdasarkan data hasil uji prasyarat, maka uji lanjut menggunakan uji non parametrik yaitu uji Wilcoxon untuk mengetahui ada tidaknya perbedaan penggunaan modul pembelajaran berbasis bounded inquiry lab. Hasil analisis dengan uji Wilcoxon kelas XI MIA 4 disajikan pada Tabel 4.

Tabel 4. Hasil Analisis Uji Wilcoxon Kelas XI MIA 4

\begin{tabular}{llll}
\hline Uji & Hasil & Keputusan & Kesimpulan \\
\hline Lanjut & $\mathrm{T}_{\text {hitung }}=-5.048$ & $\mathrm{H}_{0}$ ditolak & Hasil tidak \\
& $\mathrm{p}=0.000$ & & sama \\
& & & (ada beda) \\
\hline
\end{tabular}

Berdasarkan data hasil yang diperoleh pada kelas XI MIA 4 dapat disimpulkan bahwa nilai literasi sains dimensi konten peserta didik mengalami peningkatan setelah diberikan pembelajaran menggunakan modul berbasis bounded inquiry lab.

b. Hasil Penilaian Pengguna Modul

Hasil penilaian modul menggunakan angket dapat disaijkan pada Gambar 4.

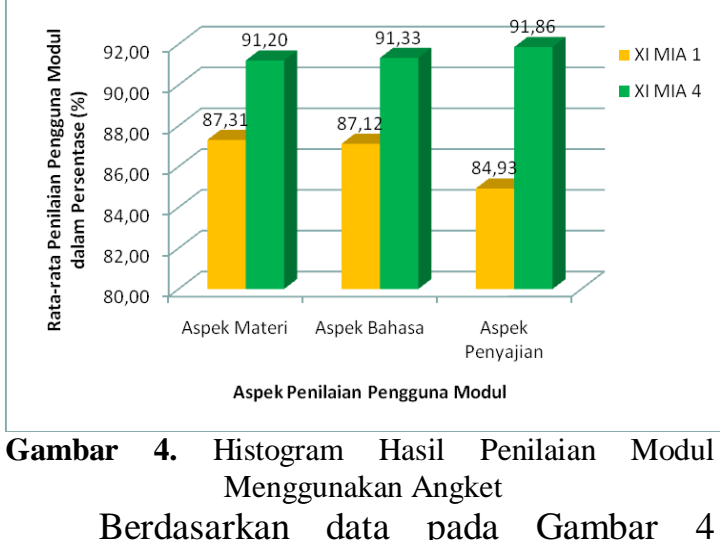
menunjukkan bahwa modul termasuk kategori baik dan memenuhi standar penyusunan modul. Hasil penilaian modul menggunakan kuesioner menunjukkan bahwa modul berbasis bounded inquiry lab memotivasi pengguna modul aktif mempelajari dan menggunakan modul, mendorong belajar mandiri untuk mengembangkan kemampuan berpikir dan berproses, serta mampu mengaplikasikan antara materi dengan kehidupan sehari-hari.

\section{Pembahasan}

1. Karakteristik Modul Berbasis Bounded Inquiry Lab Untuk Meningkatkan Literasi Sains Dimensi Konten Pada Materi Sistem Pencernaan Kelas XI 
Modul berbasis bounded inquiry lab dikembangkan sesuai tahapan sintaks bounded inquiry lab meliputi observation, manipulation, generalization, verification dan application (Wenning, 2010). Karakteristik pembelajaran menggunakan modul berbasis bounded inquiry lab pada materi Sistem Pencernaan adalah terdapat kegiatan prelab tentang keselamatan kerja dan keamanan penggunaan alat laboratorium dan bimbingan guru hanya satu kali dalam kegiatan pembelajaran (Wenning, 2011).

Karakteristik modul berbasis bounded inquiry lab berpotensi untuk meningkatkan literasi sains peserta didik khususnya pada dimensi konten karena peserta didik mampu menemukan konsep pembelajaran sendiri yang dapat dikaitkan dengan kehidupan sehari-hari. Sintaks bounded inquiry lab mampu mendorong peserta didik melakukan kerja ilmiah mandiri, melalui kegiatan merumuskan masalah, merancang kegiatan praktikum, melakukan eksperimen, menganalisis data, menyimpulkan hasil eksperimen dan menghubungkan hasil eksperimen dengan kehidupan sehari-hari, peserta didik mampu menemukan konsep. Konsep biologi erat kaitannya dengan kehidupan sehari-hari yang mengkaitkan konsep biologi dengan kehidupan sehari-hari akan membuat pembelajaran lebih bermakna dan bukan sekedar hafalan (Siregar, 2010).

Modul bounded inquiry lab merupakan modul yang sesuai untuk meningkatkan literasi sains dimensi konten karena berisi serangkaian kegiatan penyelidikan, sehingga membuat pembelajaran biologi lebih bermakna, tidak menitikberatkan pada aspek hafalan, sehingga peserta didik tidak memahami apa yang dipelajari, tetapi hanya sebatas mengingat dan sewaktu-waktu dapat dengan mudah terlupakan. Potensi dalam modul berbasis bounded inquiry lab sesuai dengan teori belajar bermakna dari Ausebel, dimana pada tahap manipulasi dan generalisasi yaitu, memberikan pembelajaran yang nyata melalui penyelidikan secara langsung. Proses penyelidikan yang dilakukan peserta didik mampu memberikan pembelajaran yang bermakna, karena peserta didik menemukan konsep secara langsung.

\section{Kelayakan Modul Berbasis Bounded} Inquiry Lab Untuk Meningkatkan Literasi Sains Dimensi Konten Pada Materi Sistem Pencernaan Kelas XI

Uji kelayakan modul berbasis bounded inquiry lab dilakukan oleh 4 validator ahli, 2 validator praktisi implementasi modul, dan uji skala kecil terhadap 10 pengguna modul. Validator yang memvalidasi modul terdiri atas ahli materi modul, ahli penyajian modul, ahli bahasa, serta ahli perangkat pembelajaran, praktisi menilai kesesuaian materi, bahasa, dan penyajian serta uji coba skala kecil dari 10 pengguna modul. Pada tahap uji kelayakan modul mendapatkan saran dan masukan dari validator, praktisi dan pengguna modul, untuk dilakukan perbaikan terhadap modul berdasarkan saran dan masukan.

Hasil validasi dari ahli dan praktisi implementasi modul menunjukkan bahwa produk modul sudah termasuk dalam kategori "sangat baik", serta uji skala kecil memperoleh hasil yang termasuk kategori "baik", sehingga modul siap layak untuk digunakan pada tahap uji coba lapangan utama, namun ada beberapa saran dan masukan yang perlu untuk diperbaiki. Perbaikan berdasarkan saran dan masukan pada aspek materi modul yaitu pemilihan salah satu dari uji makanan karbohidrat, materi pada info sains, sebagai contoh nyata fenomena Sistem Pencernaan. Perbaikan pada aspek bahasa yaitu sistematika penulisan sesuai EYD. Perbaikan pada aspek penyajian modul yaitu format aturan penulisan, pemilihan warna harus senada.

Saran dan masukan telah dilakukan revisi, sehingga memperoleh kelayakan modul dan modul dapat dipergunakan pada tahap uji coba lapangan utama/keefektivan. 
3. Keefektivan Modul Berbasis Bounded Inquiry Lab Untuk Meningkatkan Literasi Sains Dimensi Konten Pada Materi Sistem Pencernaan Kelas XI

Berdasarkan analisis $\mathrm{N}$-gain menunjukkan rata-rata $\mathrm{N}$-gain literasi sains dimensi konten kelas XI MIA 1 sebesar 0,68 dengan kategori sedang dan rata-rata $\mathrm{N}$-gain literasi sains dimensi konten kelas XI MIA 4 sebesar 0,72 dengan kategori tinggi. Berdasarkan nilai $\mathrm{N}$-gain pada kelas XI MIA 1 dan XI MIA 4 dapat disimpulkan bahwa pembelajaran dengan menggunakan modul berbasis bounded inquiry lab dapat meningkatkan literasi sains dimensi konten peserta didik dalam kategori tinggi (Hake, 1998).

Berdasarkan hasil uji Wilcoxon dan Ngain kelas XI MIA 1 dan XI MIA 4 dapat disimpulkan bahwa modul berbasis bounded inquiry lab efektif dalam meningkatkan literasi sains dimensi konten peserta didik. Peserta didik kelas XI MIA 1 dan XI MIA 4 dapat mengalami peningkatan literasi sains dimensi konten dikarenakan dalam modul berbasis bounded inquiry lab peserta didik diiajarkan guru untuk melakukan kegiatan kerja ilmiah melalui inquiry secara mandiri (Wenning, 2005b). Hal tersebut senada dengan Borthick \& Jones (2000) menyatakan bahwa perlu adanya pendekatan ilmiah yang sesuai untuk membelajarkan sains pada peserta didik. Hal ini sesuai dengan pernyataan Rakhmawan (2012) bahwa kegiatan laboratorium berbasis inquiry dapat meningkatkan literasi sains peserta didik. Inquiry merupakan pendekatan belajar dimana peserta didik menemukan dan menggunakan berbagai sumber informasi dan ide untuk menambah pemahaman peserta didik tentang suatu permasalahan. Inquiry mengembangkan kemampuan penyelidikan, observasi, penelitian dan belajar (Kuhlthau et al., 2007).

Komponen utama dari tahap-tahap model bounded inquiry lab yaitu adanya suatu permasalahan yang berkaitan dengan kehidupan sehari-hari peserta didik.
Permasalahan pada tahap observasi model ini mampu merangsang keingintahuan peserta didik dan melatih kemampuan berpikir peserta didik untuk menemukan konsep dengan menjawab pertanyaanpertanyaan melalui proses penyelidikan ilmiah. Relevan dengan Lederman (2013) menyatakan bahwa perlunya mengembangkan pemahaman pengetahuan ilmiah dengan memahami sumber dan batas pengetahuan ilmiah, sehingga lebih siap membuat keputusan yang berbasis masalah. Peserta didik dalam menemukan konsep pembelajaran melakukan tahap penyelidikan yang diperoleh dari masalahmasalah dunia nyata maupun hipotesis yang telah dilakukan peserta didik berdasarkan masalah yang ditemukan, selama proses penyelidikan peserta didik diharapkan mengkonstruk sendiri pengetahuan dan menemukan konsep-konsep baru yang relevan dengan kebutuhan peserta didik berdasarkan pengalaman langsung (Mudjiman 2006).

Pembentukan kelompok dalam pembelajaran menggunakan modul bertujuan untuk terbentuknya interaksi antar anggota kelompok dan saling berdiskusi dalam memecahkan masalah, namun peserta didik secara individu tetap wajib mengerjakan tugas secara mandiri. Sesuai dengan teori belajar Vygotsky menyatakan bahwa peserta didik dapat berinteraksi dengan kelompok secara heterogen ketika melaksanakan tugas, sehingga memiliki tanggung jawab pada tugas yang diberikan (Siregar, 2010).

Sa'ud (2008) menyatakan bahwa inquiry merupakan proses pada pencarian dan penemuan melalui proses berpikir secara sitematis. Pengetahuan bukanlah sejumlah fakta hasil dari mengingat, akan tetapi hasil dari proses menemukan sendiri. Informasi tidak hanya diberikan oleh guru, tetapi peserta didik mencari dan menemukan sendiri suatu informasi dan berusaha untuk memecahkan permasalahan yang ada. Model bounded inquiry lab berdasarkan masalah, dimana peserta didik mampu mengerjakan permasalahan yang 
autentik memerlukan konsep awal yang sudah dimiliki peserta didik sebelumnya untuk suatu penyelesaian nyata dari permasalahan yang nyata (Trianto 2010). Pada tahap manipulasi dan generalisasi yaitu, memberikan pembelajaran yang nyata melalui penyelidikan secara langsung.

Proses penyelidikan yang dilakukan peserta didik mampu memberikan pembelajaran yang bermakna, karena peserta didik menemukan konsep secara langsung. Belajar bermakna merupakan suatu proses mengkaitkan informasi baru pada konsep-konsep relevan yang terdapat dalam struktur kognitif seseorang. Berdasarkan teori Ausubel, dalam membantu peserta didik menanamkan pengetahuan baru dari suatu materi, sangat diperlukan konsep-konsep awal yang sudah dimiliki peserta didik yang berkaitan dengan konsep yang akan dipelajari. Berdasarkan pernyataan yang telah dikemukakan disimpulkan bahwa literasi sains dimensi konten peserta didik meningkat setelah diterapkan pembelajaran menggunakan modul berbasis bounded inquiry lab. Relevan dengan Johnson, et al. (2006) menyatakan bahwa pembelajaran dengan tahapan bounded inquiry lab memberikan kesempatan leluasa untuk melakukan aktivitas di laboratorium dengan metode ilmiah sesuai kemampuan berpikir dan tingkat pemahaman sains peserta didik.

\section{Kesimpulan dan Rekomendasi}

Kesimpulan yang diperoleh berdasarkan hasil penelitian pengembangan adalah: 1) karakteristik modul berbasis bounded inquiry lab pada materi Sistem Percernaan sesuai dengan sintaks bounded inquiry lab meliputi observasi, manipulasi, generalisasi, verifikasi, dan aplikasi, serta terdapat kegiatan prelab berupa keselamatan kerja dan keamanan penggunaan alat laboratorium dengan bimbingan guru hanya satu kali; 2) kelayakan modul berbasis bounded inquiry lab pada materi Sistem Pencernaan berdasarkan validator ahli dan validator praktisi implementasi modul memperoleh kategori "sangat baik", dan responden 10 pengguna modul memperoleh kategori "baik", sehingga modul berbasis bounded inquiry lab pada materi Sistem Pencernaan layak digunakan dan; 3) uji keefektivan menunjukkan $\mathrm{N}$-gain kelas XI MIA 1 dan XI MIA 4 memiliki peningkatan dengan kategori "sedang", sehingga modul berbasis bounded inquiry lab efektif untuk meningkatkan literasi sains dimensi konten.

\section{Rekomendasi}

Berdasarkan kesimpulan, maka perlu dilakukan perbaikan berdasarkan saran dalam pemanfaatan produk lebih lanjut antara lain: 1) modul berbasis bounded inquiry lab efektif untuk meningkatkan literasi sains dimensi konten, sehingga guru dapat memanfaatkan modul secara maksimal; 2) modul dapat disebarkan secara luas ke sekolah lain dalam rangka untuk meningkatkan literasi sains dimensi konten; 3) modul berbasis bounded inquiry lab menekankan pada pembelajaran penemuan dengan adanya kegiatan keselamatan kerja dan penggunaan alat laboratorium, sehingga perlu adanya perhatian dan pemahaman yang baik, serta diperlukan sarana penunjang alat dan bahan laboratorium yang lebih baik dan tepat untuk melakukan praktikum; 4) penggunaan modul berbasis bounded inquiry lab memerlukan tingkat pemahaman, ketelitian, dan fokus yang lebih baik. Diharapkan guru memahami terlebih dahulu tahapan pembelajaran berbasis bounded inquiry lab agar pelaksanaan pembelajaran berjalan lebih baik dan berhasil dan; 5) Modul dapat dikembangkan lebih lanjut oleh peneliti lain dengan cakupan materi yang lebih luas, sehingga dapat diketahui sejauh mana tingkat keefektivan modul berbasis bounded inquiry lab untuk meningkatkan literasi sains dimensi konten.

\section{Daftar Pustaka}

Borg and Gall. 1983. Education Research, And Introduction. New York \& London: Longman Inc. Choksy. 
Borthick, A. F and Jones, D. R. 2000. The Motivation for Collaborative Discovery Learning Online and Its Application in an Information Systems Assurance Course. Issues in Accounting Education, Vol. 15, No. 2. Diperoleh 24 Juni 2015.

Brickman. P., C. Gormally, N. Amstrong. \& B. Hallar. 2009. Effects of Inquiy Based Learning on Students Science Literacy Skills and Confidence. Diperoleh 29 September 2014, dari http://www.georgiasouthern.edu/ijotl.

BSNP. 2013. Pemetaan Materi Soal Biologi (Butir Soal, Kelompok, Materi, SKL) SNP SMA Negeri 7 Surakarta (Lampiran 3). Surakarta.

Campbell, N.A., J.B. Reece, \& L.G. Mitchell. 2000. Biologi. Ed Ke-5, Jilid 3. Terj. dari Biology, oleh W. Manalu. Jakarta: Erlangga.

Hake, RR. 1998. Interactive Engagement Versus Traditional Method: A SixThousand Student Survey of Mechanics Test Data for Introductory Phsyics Course. Am. J. Phus.

Hamdani. 2011. Strategi Belajar Mengajar. Bandung: Pustaka Setia.

Johnson, D., Levy, F., Karsai, I., and Stroud, K. 2006. Turning the Potential Liability of Large Enrollment Laboratory Science Courses Into an Asset. Journal of College Science Teaching. Tennesse: Department of Biological Sciences at East Tennessee State University Johnson City. Diperoleh 14 Oktober 2014, dari http://isjd.pdii.lipi.go.id/admin/jurnal /1209187194.pdf.

Johnson, S.K., \& Stewart, J. 2012. Revising and assessing explanatory models in a high school genetetic class: A comparison of unsuccessful and successful performance. Science Education, 86, 463-480.

Kemendikbud. 2013. Kurikulum 2013. Sekolah Menengah Atas(SMA)/Madrasah Aliyah (MA).

Kuhlthau, C.C, Maniotes, L.K., \& Caspari, A.K. 2007. Guided Inquiry: Learning in the 21st Century. London: Libraries Unlimited.
Lederman, N.G., Lederman, J.S., \& Antink, A. 2013. Nature of Science and Scientific Inquiry as Contexts for the Learning of Science and Achievement of Scientific Literacy. International Journal of Education in Mathematics, Science and Technology, Volume 1, Number 3, July 2013, 138-147 ISSN: 2147-611X. Diperoleh 2 Oktober 2014, dari www.ijemst.com.

Liliasari. 2011. Membangun Masyarakat Melek Sains Berkarakter Bangsa Melalui Pembelajaran. Makalah Semnas UNNES 2011. Diperoleh 8 September 2014.

2012. Membangun Masyarakat Melek Sains Berkarakter Bangsa Melalui Pembelajaran. Makalah Semnas UNNES.

Mayuri, N.S. 2013. Pengaruh Model Inquiry Lab terhadap Kemampuan Literasi Sains dan Sikap Ilmiah Siswa pada Materi Gerak pada Tumbuhan. Skripsi Tidak Diterbitkan, Universitas Pendidikan Indonesia, Bandung. Diperoleh 10 September 2014, dari http://repository.upi.edu/519/.

Mudjiman. 2006. Belajar Mandiri. Surakarta: UNS Press.

Mulyasa, E. 2006. Kurikulum Berbasis Kompetensi, Konsep, Karakteristik, dan Implementasi dan Inovasi. Bandung: Remaja Rosdakarya.

National Science Teachers Association. 2006. STS. A New Effort for Providing Appropriate Science for All. Diperoleh 3 November 2014 dari http://www.nsta.org.positionstatment:34.

Organisation for Economic Co-operation and Development. 2000. Programme For Programme For International Student International Student Assessment and Non-OECD Assessment and Non-OECD Countries Countries. Diperoleh 5 September 2014, dari http://www.oecd.org/edu/school /program meforinternational student assessmentpisa/33690591.pdf.

Organisation for Economic Co-operation and Development. 2003. Chapter 3 of the Publication "PISA 2003 Assesment of framework - mathematics, Reading, Science and Problem Solving Knowledge 
and Skills. Diperoleh 5 September 2014, dari http://www.oecd.org /dataoecd/38/29/33707226.pdf.

Organisation for Economic Co-operation and Development. 2003. Literacy Skills for the World of Tomorrow. Further Result from PISA 2000. Diperoleh 5 September 2014, dari http://www.oecd.org/edu/school/ programmefor international student assessmentpisa/33690591.pdf.

Organisation for Economic Co-operation and Development. 2009. PISA 2009 Assessment Framework, Key Competences in Reading, Mathematic and Science. Diperoleh 5 September 2014 dari http://www.oecd.org/pisa/pisaproducts/44 455820.pdf.

Organisation for Economic Co-operation and Development. 2009. Take the Test. Sample Questions from OECD's PISA Assessments. Diperoleh 5 September 2014, dari

http://browse.oecdbookshop.org/oecd/pdfs /free/9809051e.pdf.

Organisation for Economic Co-operation and Development. 2012. Results Students and Money Financial Literacy Skills For The $21^{\text {st }}$ Century Volume VI. Diperoleh 5 September 2014. http://www.oecd.org/pisa/keyfindings/PIS A-2012-results-volume-vi.pdf.

Parmin. 2009. Aktivitas Peserta Didik Dalam Pembelajaran IPA melalui Lesson Study. Jurnal Varia Pendidikan, 21 (1): 1-11. Diperoleh 3 Mei 2015.

Peraturan Menteri Pendidikan dan Kebudayaan No. 64 Tahun 2013. 2013. Standar Isi Pendidikan Dasar dan Menengah. Diperoleh 5 September 2014. http://www.pendis.kemenag.go.id/pai/file/ dokumen/06.B.SalinanLampiranPermendi kbudNo.64th2013ttgStandarIsi.pdf.

Peraturan Menteri Pendidikan dan Kebudayaan No. 69 Tahun 2013. 2013. Kerangka Dasar dan Struktur Kurikulum Sekolah Menengah Atas/Madrasah Aliyah. Diperoleh 5 September 2014. http://biologi.fkip.uns.ac.id/wp-content/ uploads /2013/08/PDK-2013-69Kerangka-Dasar-Kurikulum-KompetensiSMA.pdf.
PISA. 2006. Science Competencies for Tomorrow's World Volume 1-analysis. OECD. Diperoleh 5 September 2014, dari www.oecd.org/statistics/statlink.

Prastowo, Andi. 2012. Panduan Kreatif Bahan Ajar Inovatif. Yogyakarta: Diva Press

Purwanto, Liliawati, W., dan Hidayat, R. 2013. Analisis Kemampuan Inkuiri dan Hasil Belajar Siswa Sekolah Menengah Pertama melalui Model Pembelajaran berbasis Model Hierarki Of Inquiry. Prosiding Pertemuan Ilmiah XXVII HFI Jateng \& DIY, Solo, 2 Maret 2013. ISSN : 08530823.

Rakhmawan, A. 2012. Kegiatan Laboratorium Berbasis Inkuiri Pada Sub Materi Pokok Sel Volta Untuk Meningkatkan Literasi Sains Siswa SMA. Tesis Tidak Dipublikasikan. Universitas Pendidikan Indonesia.

Riduwan. 2004. Metode dan Teknik Menyusun Tesis. Alfabeta. Bandung.

Riyanto, Yatim. 2010. Paradigma Baru Pembelajaran. Jakarta: Kencana Prenada Media Grup.

Rustaman, N. 2005.Strategi Belajar Mengajar Biologi. Malang: UM Press.

Sanjaya, Wina. 2006. Strategi Pembelajaran Berorientasi Standar Proses Pendidikan. Jakarta: Kencana Prenadamedia Group.

Saud, U. 2008. Pengembangan Profesi Guru. Bandung: Alfbeta.

Siregar, E dan Nara, H. 2010. Teori Belajar dan Pembelajaran. Bogor: Ghalia Indonesia.

Suciati Sudarisman. 2011. Membangun Karakter Peserta Didik Melalui Pembelajaran Biologi Berbasis Keterampilan Proses. Proceding Seminar Nasional VII Pendidikan Biologi FKIP UNS.

Sumartati, L. 2009. Pembelajaran IPA Terpadu Pada Tema Makanan dan Pengaruhnya Terhadap Kerja Ginjal Untuk Meningkatkan Literasi Sains Siswa MTs. Tesis. Sekolah Pascasarjana UPI.

Susanti, W. 2012. Analisis Profil Soal-sola Literasi Sains Kategori Sulit Pada Tes PISA. Jurusan Pendidikan Biologi FPMIPA UPI.

Suyanti, Retno Dwi. 2010. Strategi Pembelajaran Kimia. Yogyakarta:Graha ilmu. 
Toharudin,U. Hendrawati, S. Rustaman, A. 2011 .Membangun Literasi Sains. Bandung : Humaniora.

Trianto. 2010. Mendesain Model Pembelajaran Inovatif-Progresif: Konsep, Landasan, dan Implementasinya pada Kurikulum Tingkat Satuan Pendidikan (KTSP). Jakarta: Kencana.

Undang-Undang RI No, 20 Tahun 2003 Pasal 1. 2003. Sistem Pendidikan Nasional. Diperoleh $1 \quad$ Oktober 2014. http://www.unpad.ac.id/wpcontent/uploads/2012 /10/UU20-2003Sisdiknas.pdf.

Wenning, C. J. 2005. Levels of Inquiry: Hierarchies of Pedagogical Practices and Inquiry Processes. Journal of Physics Teacher Education Online, 2(3), February 2005.

. 2005b. Implementing Inquiry-Based Instruction in The Science Classroom: A New Model For Solving The Improvement-of-Practice Problem. Journal of Physics Teacher Education Online, 2(4).

. 2007. Assessing Inquiry Skills as a Component of Scientific Literacy. Journal of Physics Teacher Education Online, 4(2), Winter 2007. Illinois State University Physics Dept.

2010. Levels of Inquiry: Using Inquiry Spectrum Learning Sequences to Teach Science. Journal of Physics Teacher Education Online, 5(4), 11-20.

2011. The Levels of Inquiry Model of Science Teaching. Journal of Physics Teacher Education Online. 6(2), Summer.

Winkel. 2009. Psikologi Pengajaran. Yogyakarta: Media Abadi.

Yusuf. S. 2003. Literasi Siswa Indonesia Laporan PISA 2003. Jakarta: Pusat Penilaian Pendidikan.[Online]. Tersedia: http://www.p4tksains.org. 
JURNAL INKUIRI

ISSN: 2252-7893, Vol. 6, No. 3, 2017 (hal 1-16)

http://jurnal.uns.ac.id/inkuiri 